\title{
AN ANALYSIS OF AIR TEMPERATURE RECORDS FOR MACQUARIE ISLAND: DECADAL WARMING, ENSO COOLING AND SOUTHERN HEMISPHERE CIRCULATION PATTERNS
}

\author{
by D.A. Adamson, P. Whetton and P.M. Selkirk
}

(with five text-figures)

ADAMSON, D.A., WHETTON, P. \& SELKIRK, P.M., 1988 (viii): An analysis of air temperature records for Macquarie Island: decadal warming, ENSO cooling and Southern Hemisphere circulation patterns. Pap. Proc. R. Soc. Tasm., 122(1): 107-112. Papers presented at the Macquarie Island Symposium, Hobart, May 1987. https://doi.org/10.26749/rstpp.122.1.107 ISSN 0080-4703. School of Biological Sciences and Quaternary Research Unit, Macquarie University, Sydney, Australia 2109; and Department of Geography, Monash University, Clayton, Australia 3168.

Macquarie Island lies close to, but on the eastern side of the boundary between the eastern (Pacific) and western (India-Australia) limbs of the Southern Oscillation. Its temperature record matches that of the area east and southeast of New Zealand, rather than Tasmania. Temperature is influenced by atmospheric pressures in the Southern Ocean to the east and west, which can result in a warm northeasterly or cold southerly airflow over the island. It is a sensitive indicator of climatic trends because of its location at high latitude in a longitudinal region of frequent ridge formation and blocking in the Southern Hemisphere circulation.

Temperature records for Macquarie Island (1949-86) show a $1^{\circ} \mathrm{C}$ warming trend (twice the global average), accelerating in the last 20 years with eight of the ten warmest years occurring in the last decade. The greatest average rate of warming has occurred in late summer and early autumn and the lowest in spring. In severe ENSO years the island cools. The warming is marked, in relation to the annual mean $\left(4.8^{\circ} \mathrm{C}\right)$, and the biological effects should be considered. Key Words: atmospheric change, climatic warming, Southern Oscillation (SO), EI Nino-Southern Oscillation (ENSO), Macquarie Island.

\section{INTRODUCTION}

The world has warmed by about $0.5^{\circ} \mathrm{C}$ over both land and ocean during this century, the Southern Hemisphere showing a more regular increase than the Northern (Folland et al. 1984, Jones et al. 1986). High latitudes in the Northern Hemisphere show amplified temperature changes compared to lower latitudes (Kelly et al. 1982, Raper et al. 1983), in conformity with theoretical predictions (Polar Review Group 1980). In the Southern Hemisphere, Jacka et al. (1984) noted a warming trend which was more pronounced at higher latitudes. North of Macquarie Island, Salinger \& Gunn (1975) showed that New Zealand warmed markedly from about 1935 to 1970, a period when cooling interrupted the longer-term warming trend in the Northern Hemisphere.

Climatic data are scarce in the Southern Hemisphere south of about $45^{\circ} \mathrm{S}$ (Salinger \& Gunn 1975, Jones et al. 1986). Macquarie Island ( $54^{\circ} 30^{\prime} \mathrm{S}$, $158^{\circ} 56^{\prime} \mathrm{E}$ ), one of the few sites suitable for supplying such information, has the additional advantage that it lies southeast of the Australian continent, where the westerly circulating Southern Ocean and atmosphere impinge upon the southwestern Pacific Ocean. Van Loon \& Shea (1987) point out the interest of this region because of its possible involvement in the Southern Oscillation (SO).

The present paper analyses the marked warming that has been recorded on Macquarie Island, at the meteorological station situated $6 \mathrm{~m}$ above sea level near the northern end of the island. The regional meteorological context and links to $\mathrm{SO}$ are also considered. Sources of data are Jacka et al. (1984), supplemented by meteorological records held on the island.

\section{TEMPERATURE TRENDS}

Macquarie Island mean annual surface temperature shows a marked upward trend of about $1{ }^{\circ} \mathrm{C}$ since annual records commenced in 1949 (fig. I). Eight of the ten warmest years have occurred during the past decade, whereas none occurred during the first 19 years of the record. Warming has occurred in all months (fig. 2), with the largest rise in monthly mean $\left(0.042^{\circ} \mathrm{C}\right.$ per 


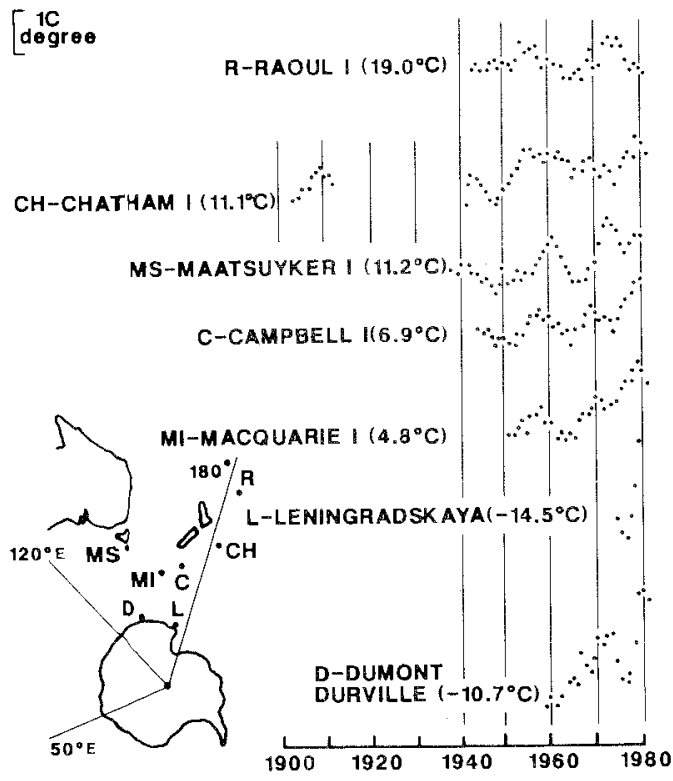

FIG. 1 - Five-year running means of annual mean temperature (mean for whole record in brackets) at stations in the region east and south of New Zealand and eastern Australia.

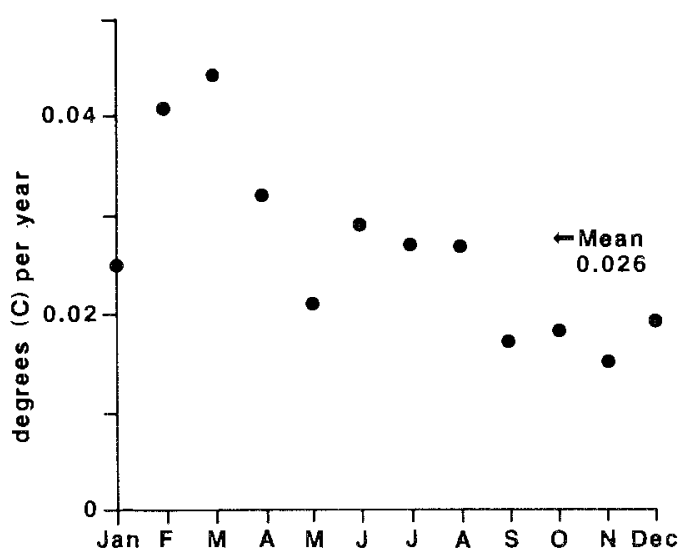

FIG. 2 - The rate of temperature increase at Macquarie Island month by month over 38 years from 1949 to 1986. The mean rate for all months is shown. annum) occurring in late summer and early autumn and the smallest $\left(0.018^{\circ} \mathrm{C}\right.$ per annum) in spring. The shape of the seasonal cycle in rate of warming is opposite to that of the latitudes of both the mean northern limit of antarctic sea ice (Jacka 1983) and the subtropical high-pressure zone (Pittock 1971). In effect, the rate of warming on Macquarie Island is greatest when the sea ice is furthest away and the mid-latitude high-pressure zone is closest, presumably because of the increased probability of warm northern air penetrating southward to the island.

\section{REGIONAL TEMPERATURE AND PRESSURE CONTEXT}

Figure 1 shows temperature trends at stations near the longitude of Macquarie Island. With the exception of Raoul Island at $19^{\circ} 15^{\prime} \mathrm{S}$, they show a warming trend that becomes more obvious southwards. The temperature records for Macquarie and Campbell Islands are remarkably similar in their patterns of warmer and cooler periods, with Chatham Island somewhat less so. Maatsuyker Island shows a different pattern. The graphs of five-year running means of annual temperature suggest that the Macquarie Island trends are more closely linked to the region southeast and east of New Zealand than to Tasmania.

The regional affinities of the climate of Macquarie Island are shown by several studies of Southern Hemisphere atmospheric pressure. Berlage (1957) correlated monthly surface pressure at stations around the world with that at Djakarta to show the extent of SO, the fluctuation in pressure between an eastern area, centred on the central and eastern south Pacific, and a western area, centred on the Australian-Indonesian-Indian Ocean region. In his analysis, the Southern Ocean southeast of New Zealand is part of the eastern limb, whereas Tasmania and part of the Southern Ocean south of Australia lie within the western limb of SO. Macquarie Island lies near the boundary between these two vast areas of opposite pressure anomalies. Numerous, more recent analyses confirm a major boundary in the global circulation in the general region of Macquarie Island, with a tendency for the island to lie just within the eastern limb of SO (Trenberth 1976, van Loon \& Madden 1981, Pan \& Oort 1983, van Loon \& Shea 1985, 1987, Gordon 1986).

Figure 3 shows the correlation between anomalies of monthly mean sea-level atmospheric pressure throughout the Australian-New Zealand 


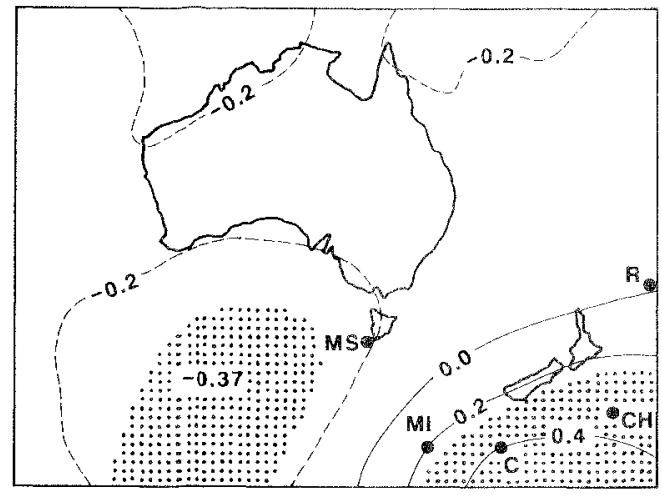

FIG. 3 - Correlation map of Macquarie Island detrended monthly mean temperature anomalies and monthly mean sea-level atmospheric pressure anomalies in the Australia-New Zealand region. The period analysed was 1970-80 (132 months) The shaded area shows correlation significant at the $1 \%$ level, allowing for reduction in the number of data points due to persistence. The meteorological stations shown on figure I are indicated.

region and temperature on Macquarie Island. For this analysis the long-term warming trend shown on Macquarie Island was removed. The map shows clearly the opposite behaviour of the Southern Ocean to the east and to the west of the island, and the affinity of Macquarie Island with the region east and southeast of New Zealand. The correlation map can be interpreted as showing an effect of wind direction on temperature. When the atmospheric pressure is high to the east of Macquarie Island (positive anomalies) and low to the west (negative anomalies), the wind direction in the MacquarieCampbell region reflects the anticyclonic conditions and is more northeasterly than usual, thereby bringing warmer northern air southwards. Ridge formation and blocking over the Tasman Sea-New Zealand region (Wright 1974, Ramaswamy \& Pareek 1978, Pierrehumbert et al. 1984, Trenberth \& Mo 1985) may also direct warm northern air southwards to Macquarie Island. Invasion by northern air from New Zealand and Australia is an obvious means of long-distance dispersal for organisms. For example, the redpoll probably arrived from New Zealand on winds associated with high pressure to the east of the island. Organisms will no doubt continue to arrive on Macquarie Island by natural wind dispersal. By contrast, when there is anomalously high pressure south of Australia and low pressure southeast of

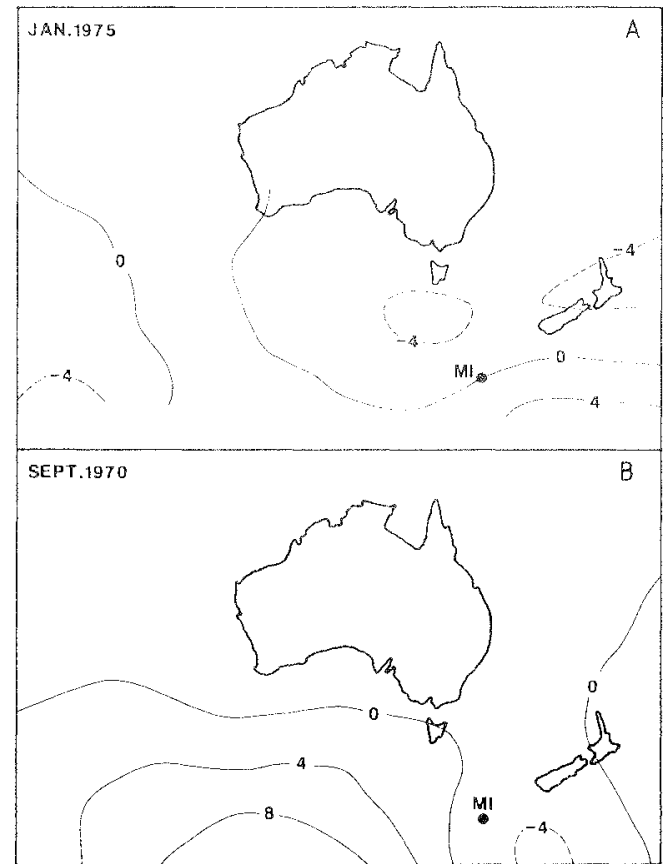

FIG.4-(A) Mean sea-level atmospheric pressure anomalies $(m b)$ for January 1975 when the largest monthly positive temperature anomaly $\left(+1.9^{\circ} \mathrm{C}\right)$ occurred at Macquarie Island (MI). (B) Mean sealevel atmospheric pressure anomalies $(m b)$ for September 1970 when the largest monthly negative temperature anomaly $\left(-1.3^{\circ} \mathrm{C}\right)$ occurred at Macquaric Island (MI).

New Zealand, cold southern air flows from the southwest over Macquarie Island.

Figure 4 shows the monthly mean pressure anomalies for two months during which extreme high and extreme low temperatures respectively occurred on Macquarie Island. These months illustrate the generalised picture shown in the correlation map (fig. 3). In January 1975, record high temperatures for the month were recorded on Macquarie Island $\left(9.1^{\circ} \mathrm{C}\right)$ and on Campbell Island $\left(11.0^{\circ} \mathrm{C}\right)$; Chatham Island was also unusually warm. As expected from figure 3 , anticyclonic conditions east of Macquarie Island and southeast of New Zealand directed warm northern air over the island; similar conditions applied to Campbell and Chatham Islands. A contrary situation applied in 1970 , when record lowest September temperatures were recorded for Macquarie Island $\left(2.2^{\circ} \mathrm{C}\right.$, equal to that in 1954) and Campbell Island $\left(4.3^{\circ} \mathrm{C}\right)$. Low 


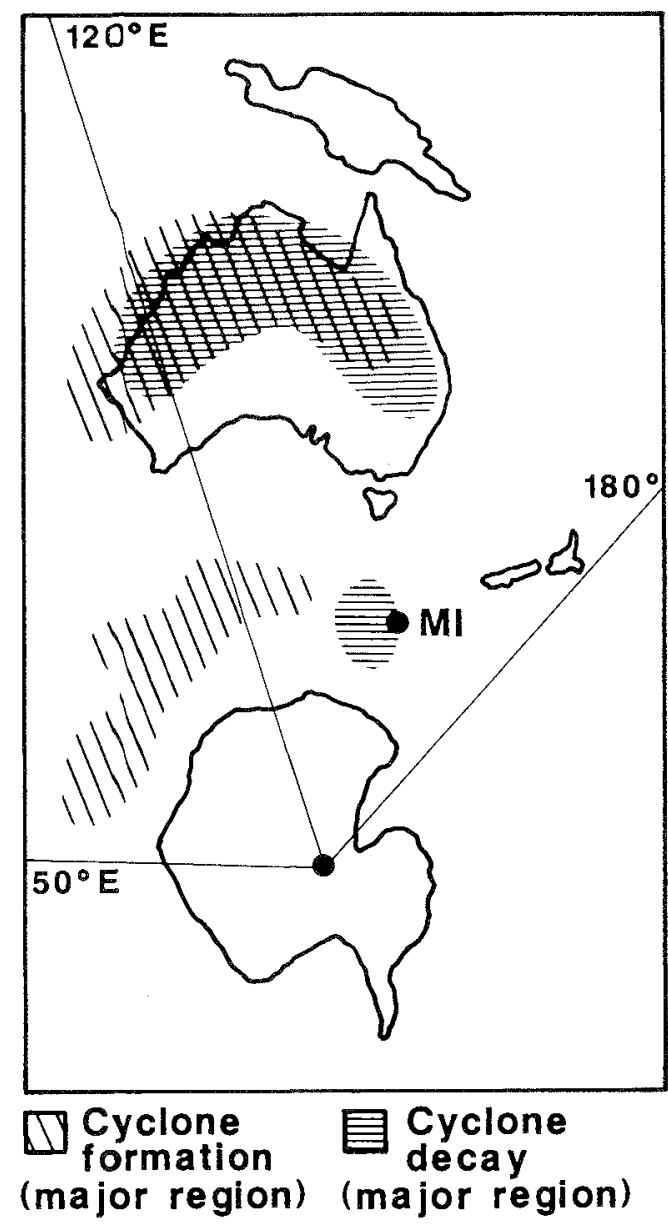

FIG. 5 - Locations of cyclone formation and decay in the Australia-New Zealand-Southern Ocean region. MI - Macquarie Island. Modified from Kep (I984).

pressure to the east and high pressure to the west of Macquarie Island directed cold southern air northwards over these two islands. However, Chatham Island was warmer than average, being under the influence of persistent northerly flow.

The contrast between the Macquarie Island region of the Southern Ocean and similar latitudes to the west is also shown in figure 5. Macquarie Island is in an area of cyclone decay. Few cyclones form there or to the east, but to the west lies one of the most intense areas of cyclone formation in the Southern Ocean (Rice 1982, Kep 1984). The area of intense cyclogenesis lies south of the Indian Ocean and western Australia where the largest waves in the Southern Ocean are generated. To the south of this region, Deacon (1984) noted recent retreat of the northern limit of summer sea ice around Antarctica. Examination of the data compiled by Jacka (1983) for the period 1973-83 shows a southwards retreat of sea ice in February by $2^{\circ}$ to $4^{\circ}$ latitude in the sector of the coast from about $50^{\circ} \mathrm{E}$ (Enderby Land) to about $180^{\circ}$ to $160^{\circ} \mathrm{W}$ (Ross Sea). By contrast, minor retreat occurred south of the Pacific Ocean and none in the sector from the Atlantic Ocean to south of Madagascar.

\section{EFFECT OF THE SOUTHERN OSCILLATION}

Consequences of the SO seesaw in atmospheric pressure, sea-surface temperature and rainfall extend far beyond the tropics and subtropics of the region extending from India to the Americas. Influences can also be recognised or inferred around the globe at middle and high latitudes in both hemispheres (Ramaswamy \& Pareek 1978, Chen 1982, Harnack \& Harnack 1985, Raman \& Maliekal 1985, Hense 1986, Peng \& Domros 1987, van Loon \& Shea 1987, Wolter 1987).

Echoes of SO appear in the Macquarie Island temperature record. The two most severe negative excursions of the SO index during this period occurred in 1972-73 and 1982-83 and corresponded closely with periods when the island was notably cold. Another period of severe cold in 1963 matched a period of negative SO index. During periods of negative index, which are called El Nino-Southern Oscillation (ENSO) events, high pressure anomalies, droughts and weak monsoons occur over the Australian-Indonesian-Indian region, while the opposite conditions occur over the central and eastern Pacific. As previously noted, Macquarie Island lies near, but to the east of the boundary between these two huge regions. High pressure anomalies to the west of Macquarie Island and negative ones to the east (figs $3 \& 4$ ) favour cold southerly circulation over the island and lead to negative temperature anomalies during severe ENSO events. Over New Zealand, Trenberth (1975) noted a switch to persistently cold southwesterly air flow in the severe ENSO year of 1972. Of course, other parts of the globe behave differently; for example, Northern Hemisphere land between $0^{\circ}$ and $25^{\circ} \mathrm{N}$ warms during ENSO events (Bradley et al. 1987). Possibly the marked cooling on Macquarie Island and the associated pressure 
anomalies during severe ENSO events are both related to a globally stronger meridional circulation at such times.

\section{DISCUSSION}

The warming on Macquarie Island fits the global temperature trend this century (Folland et al. 1984, Jones et al. 1986). That carbon-dioxideind uced warming of the lower atmosphere may be involved as a cause is suggested by the observation (Karoly, in press) that significant warming has occurred in the troposphere at $700 \mathrm{mb}$ altitude over Macquarie Island, along with cooling in the lower strat osphere at $50 \mathrm{mb}$ altitude. Karoly found that a number of other Southern Hemisphere meteorological stations show similar patterns. This vertical temperature pattern of warming at lower levels and cooling above is consistent with retention of heat in the troposphere by a carbon dioxide blanket.

Warming has occurred at subantarctic and oceanic islands lying south of the western limb of SO, that is south of the tropical Indian Ocean and of Australia, including Kerguelen Island, Marion Island, New Amsterdam Island (Jacka et al. 1984) and Heard Island (Allison \& Keage 1986). At these oceanic islands, temperature trends extending over a few decades must reflect similar trends in ocean temperature. On Macquarie Island, Loewe (1957) noted a close connection between simultaneous temperatures of the ocean and the air during 1951-54. He also noted that sea temperatures in 1951-54 were higher than in 1912-14, and that the greatest increase was during summer. The monthby-month increase in sea temperature between the two periods shows the same pattern as that for air temperature from 1949-86 shown in figure 2 . There can be little doubt that sea temperatures around Macquarie Island are also warming. Although changes in sea-surface temperature and atmospheric circulation patterns have undoubtedly occurred, their interactions and relative contributions to the warming trend are not known.

Macquarie Island lies at a preferred location for formation of a ridge in the planetary waves of the Southern Hemisphere (van Loon \& Jenne 1972, Mo 1986) and near a longitude of frequent blocking and ridge formation (Wright 1974, Ramaswamy \& Pareek 1978, Trenberth \& Mo 1985), as well as at the junction between western and eastern limbs of SO. This key location in the Southern Hemisphere atmospheric circulation, as well as its isolation in the high latitudes, makes the island an indispensible meteorological station, particularly for upper atmospheric studies.
The temperature rise of $1^{\circ} \mathrm{C}$ since 1949 is substantial, in view of the mean annual temperature of $4.8^{\circ} \mathrm{C}(1949-86)$ and the probability that warming was occurring earlier this century. Because the warming is marked in relation to the annual mean, the biological consequences should be addressed. Population size and distribution of plants, seals and sea birds may be affected if the long-term temperature increase continues.

\section{ACKNOWLEDGEMENTS}

We thank Mr Steve Manning and the 1986-87 staff from the Bureau of Meteorology for access to meteorological records and for warm hospitality on the island. Permission from the Macquarie Island Advisory Committee to work on the island, and logistic support from the Australian Antarctic Division are gratefully acknowledged. Financial support was provided by an Australian Research Grants Scheme Programme Grant, a Macquarie University Research Grant and a National Research Fellowship. Diagrams were drafted by G. Rankin and the original manuscript was typed by $S$. Hummelstad.

\section{REFERENCES}

ALLISON, I.F. \& KEAGE, P.L., 1986: Recent changes in the glaciers of Heard Island. Polar Rec., 23: 255-271.

ARDENNY, P.E. \& KYLE, H.L., 1986: El Nino and outgoing longwave radiation: Observations from Nimbus-7 ERB. Monthly Weather Rev., 14: $415-433$.

BERLAGE, H.P., 1957: Fluctuations of the general atmospheric circulation of more than one year, their nature and prognostic value. Koninklijk Neder. Met. Inst., Mededelingen en Verhandelingen, 69: 1-152.

BRADLEY, R.S., DIAZ, H.F., KILADIS, G.N. \& EISCHEID, J.K., 1987: ENSO signal in continental temperature and precipitation records. Nature, 327: 497-501.

CHEN, W.Y., 1982: Fluctuations in Northern Hemisphere $700 \mathrm{mb}$ height field associated with the Southern Oscillation. Monthly Weather Rev., 1 10: 808-823

DEACON, G., 1984: THE ANTARCTIC CIRCUMPOLAR OCEAN. Cambridge University Press, Cambridge.

FOLLAND, C.K., PARKER, D.E, \& KATES, F.E. 1984: Worldwide marine temperature fluctuations 1856-1981. Nature, 310: 670-673.

GORDON, N.D., 1986: The Southern Oscillation and New Zealand weather. Monthly Weather Rev., 114: $371-387$ 
HARNACK, R.P. \& HARNACK, J., 1985: Intra and inter-hemispheric teleconnections using seasonal Southern Hemisphere sea level pressure. $J$. Clim., 5: 283296

HENSE, A., 1986: Multivariate statistical investigations of the northern hemisphere circulation during the El Nino event 1982/83. Tel/ss, 38 A: 189204

JACKA, T.H., 1983: A computer data base for Antaretic sea ice extent. ANARERes. Notes, 13. Antarctic Division, Kingston, Tasmania.

JACKA, T.H., CHRISTOU, L. \& COOK, B.J., 1984: A data bank of mean monthly and annual surface temperatures for Antarctica, the Southern Ocean and South Pacific Ocean. ANARE Res. Notes, 22. Antarctic Division, Kingston, Tasmania.

JONES, P.D., WIGLEY, T.M L \& WRIGHT, PB 1986: Global temperature variations between 1861 and 1984. Nature, 322: 430-434.

KAROLY, D.J., in press: Southern Hemisphere temp erature trends: a possible greenhouse gas effect? Geophys. Res. Lett.

KELLY, P.M., JONES, P.D., SEAR, C.B., CHERRY, B.S.G.\& TAVAKOL, R.K., 1982: Variations in surface air temperatures: Part 2. Arctic regions, 1881-1980. Month/y Weather Rev., 110:71-83.

KEP, S.L., 1984: A climatology of cyclogenesis, cyclone tracks and cyclolysis in the Southern Hemisphere for the period 1972 1981. Mel. Dep. Univ. Melbourne Publication, 25. Parkville, Victoria.

LOEWE, F., 1957: A note on sea water temperature at Macquarie Island. Aust. Met. Mag., 19:60-61.

MO, K.C., 1986: Quasi-stationary states in the Southern Hemisphere. Monshly Weather Rev., 114: $808-823$.

PAN, Y.H. \& OORT, A.H., 1983: Global climate variations connected with sea surface temperature anomalies in the eastern equatorial Pacific Ocean for the 1958-73 period. Monthly Weather Rev., 111: 1244-1258.

PENG, G. \& DOMROS, M., 1987: Connections of the west Pacific subtropical high and some hydroclimatic regimes in China with Antarctic icesnow indices. Met. Atmos. Phys., 37: 61-71.

PIERREHUMBERT, C., POWELL, F.A. \& OLIVER, S., 1984: Continental transport of particulate matter between Aust ralia and Macquarie island. In Hartmann, H.F. , O'Heare, J.N., Chiodo, J. \& Gillis, R. (Eds): PROCEEDINGS OF THE EIGHTH INTERNATIONAL CLEAN AIR CONFERENCE. The Clean Air Society of Australia and New Zealand (2): $741 \cdots 750$.

PITTOCK, A.B., 1971: Rainfall and the general circulation. PROCEEDINGS OF THE INTERNATIONAL CONFERENCE ON WEATHER MODIFICATION. American Meteorological Society: $330-339$.

POLAR REVIEW GROUP, 1980; Polar atmosphere-ice-ocean processes: A review of polar problems in climate research. Rev. Geophys. \& Space Phys., 18: 525-543.
RAMAN, C.R.V. \& MALIEKAL, J.A., 1985: A "northern oscillation" relating northern hemisphere pressure anomalies and the Indian summer monsoon. Nature, 314: 430 432.

RAMASWAMY, C. \& PAREEK, R.S., 1978: The southwest monsoon over India and its tele connections with the middle and upper tropospheric flow patterns over the Southern Hemisphere. Tellus, 30:126-135

RAPER, S.C.B., WIGLEY, T.M.L., JONES, P.D. KELLY, P.M. MAYES, P.R. \& LIMBERT, D.W.S., 1983: Recent temperature changes in the Arctic and Antarctic. Nalure, 306:458-459.

RICE, J.E., 1982: The Derivation of a Computer-based Synoptic Climatology of Southern Hemisphere Extra-Tropical Cyclones. Unpublished B.Sc. Honours thesis, University of Melbourne.

SALINGER, M.J.\& GUNN, J.M., 1975: Recent climatic warming around New Zealand. Nature, 256: $396 \cdots 398$.

TRENBERTH, K.E., 1975: A quasi-biennial standing wave in the Southern Hemisphere and interrelations with sea surface temperature. Quar. $J$. R. Met. Soc., 101: 55-74.

TRENBERTH, K.E., 1976: Spatial and temporal variations of the Southern Oscillation. Quar. J. R. Met. Soc., 102: 639-653.

TRENBERTH, K.E.\& MO, K.C., 1985: Blocking in the Southern Hemisphere. Monthly Weather Rev. 113:3-21

VAN LOON, H. \& JENNE, R.L., 1972: The zonal harmonic standing waves in the Southern Hemisphere. J. Geophys. Res., 77: 992-1003.

VAN LOON, H. \& MADDEN, R.A., 1981: The Southern Oscillation. Part 1: Global associations with pressure and temperature in northern winter. Monthly Weather Rev., 109: 1150-1162.

VAN LOON, H, \& SHEA, D.J, 1985: The Southern Oscillation. Part IV. The precursors south of $15^{\circ} \mathrm{S}$ to the extremes of the oscillation. Monthly Weather Rev., 113: 2063-2074.

VAN L.OON, H. \& SHEA, D.J., 1987: The Southern Oscillation. Part VI: Anomalies of sea level pressure on the Southern Hemisphere and of Pacific sea surface temperature during the development of a warm event. Monthly Weather Rev., 115: 370-379.

WOLTER, K., 1987: The Southern Oscillation and climate over tropical Atlantic, East Pacific and Indian Oceans as captured by cluster analysis. $J$. Clim. Appl. Met, 26: 540-558.

WRIGHT, A.D.F., 1974: Blocking action in the Australian region. Bur. Met. Aust. Tech. Rep. 10: $1-29$.

(accepted 5 October 1987) 